Saudi Journal of Business and Management Studies Abbreviated Key Title: Saudi J Bus Manag Stud ISSN 2415-6663 (Print) |ISSN 2415-6671 (Online) Scholars Middle East Publishers, Dubai, United Arab Emirates Journal homepage: https://saudijournals.com/sibms

Original Research Article

\title{
The Effect of Transformational Leadership, Perceived Organizational Support and Workload on Turnover Intention Sharia Banking Company in Jakarta
}

\author{
Noviana Masta $^{1^{*}}$, Setyo Riyanto ${ }^{2}$ \\ ${ }^{1}$ Student of Magister Management Departement, Mercu Buana University Jakarta, Indonesia \\ ${ }^{2}$ Lecturer of Magister Management Departement, Mercu Buana University Jakarta, Indonesia
}

DOI: $10.36348 /$ sjbms.2020.v05i08.003 $\quad$ | Received: 13.08 .2020 | Accepted: 21.08 .2020 | Published: 24.08 .2020

*Corresponding author: Noviana Masta

Abstract

Nowadays, although the technology keeps developing, the quantity of human resources who have competence and expertise in sharia economic continues to be minimum. It gives several direct impacts on sharia banking. One of the direct impacts is high turnover intention. The purpose of this study was to look at the Transformational Leadership effect, Perceived Organizational Support, and Workload on Turnover Intention in one of sharia banking in Jakarta. Samples of the study were employees who worked at one of sharia banking in Jakarta. Sampling was conducted using nonprobability techniques, which is purposive sampling with the Slovin formula of 101 people. This study was conducted quantitatively, and the analysis method used in this study was multiple linear regression analysis. The results of the study showed that transformational leadership, perceived organizational support and workload variables have a significant effect on turnover intention. The result of the study also showed that what affects turnover intention the most is workload. It was proven by the results of the simultaneous test (F test) and partial test ( $\mathrm{t}$-test) which showed the numerous value of three independent variables that supported the hypothesis.

Keywords: Transformational Leadership, Perceived Organizational Support, Workload, Turnover Intention.

Copyright @ 2020: This is an open-access article distributed under the terms of the Creative Commons Attribution license which permits unrestricted use, distribution, and reproduction in any medium for non-commercial use (NonCommercial, or CC-BY-NC) provided the original author and source are credited.

\section{INTRODUCTION}

In Indonesia, the constantly growing digital era of technology has made several impacts on the sharia banking industry. One of the impacts is the emergence of new competitors who can seize a sharia banking market share. According to the Financial Services Authority [49], the market share of sharia banking can only reach $5.94 \%$. This is also the result of the minimum amount of human resources who have expertise and competence in sharia economics. Therefore, it has a direct impact on sharia banking if it is not balanced with good corporate behavior and appropriate to its employees. Another impact on the company is a high turnover intention. Turnover intention is someone's desire or intention to leave both the company and their job. A high turnover intention for employees is found in one of sharia banking in Jakarta. One indication of the high turnover intention in the company is an increase in turnover rate from 2017 of $1.40 \%$, in 2018 of $1.42 \%$, and 2019 of $3.66 \%$. As well as the discovery of more employees who left the company than those who entered. The results of the prequestionnaire conducted on 30 employees showed a high turnover intention. The results of the prequestionnaire showed that there is a total average percentage of $75 \%$ which indicates that employees have the desire to leave the company if there are other companies that offer better wages, better career paths, more guaranteed employee welfare as well as the employees have plans to find job vacancies at other companies. The indication of high turnover intention in a sharia banks in Jakarta can be seen from several things which are related to the behavior of the employee. One of the indications is the increase in the work procedure violations. It is shown in the graph below: 


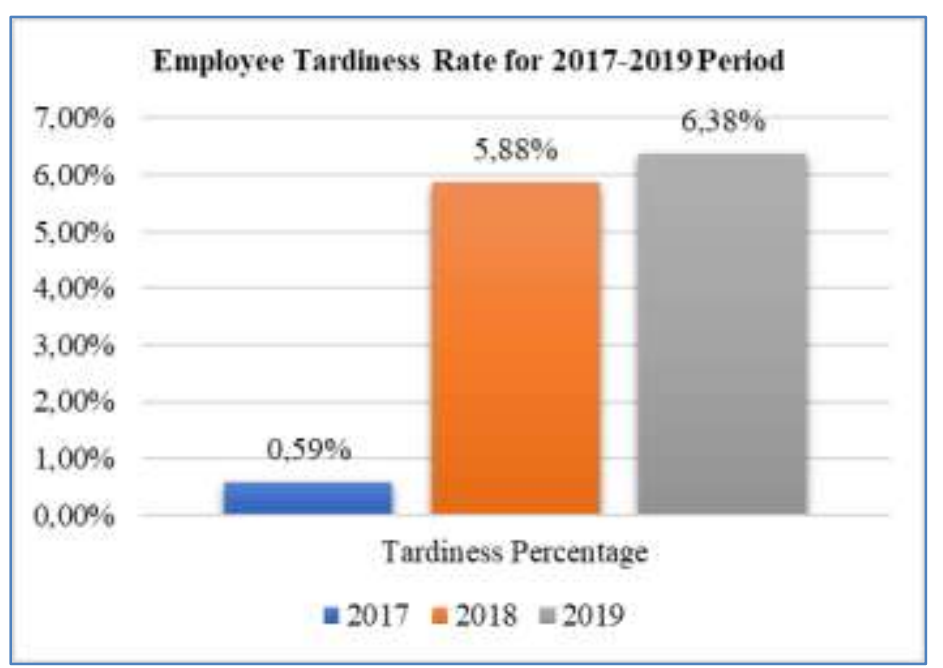

Fig-1: Employee Tardiness Rate for 2017-2019 Period

Source: Company data

The graph showed that there has been high employee tardiness in working for three consecutive years. The high percentage of employee tardiness indicates the high desire of employees to leave the company where many employees start violating work rules by coming late. The author conducted a pre-survey of 30 employees to find out what factors and variables which affect the high turnover intention of this sharia bank in Jakarta. From the results of the pre-survey, it was found that 3 main factors were considered to be very affecting the turnover intention, including transformational leadership of $87 \%$, perceived organizational support of $73 \%$, and the workload of $67 \%$. Therefore, the author needs to conduct a study entitled "The Effect of Transformational Leadership, Perceived Organizational Support, and Workload on Turnover Intention Sharia Banking Company in Jakarta".

\section{LITERATURE REVIEW \\ Transformational Leadership}

Robbin and Judge [1] stated that leadership is the capability to influence a gaggle by achieving a group vision or goal. According to Bass in Yukl [2], with transformational leadership, followers are stimulated to do more than initially expected. Besides that, they will become loyal, admire, trust, and respect for leaders. Meanwhile, according to Mickahail and Aquino [3], transformational leadership is described as an inspirational and collaborative figure. According to Sultana and Jabeen [4], leaders, whose transformational leadership qualities are good, are always involved in appealing behavior, encourage their followers' enthusiasm, and know-how to treat their followers well. Also, followers will unconsciously follow their leader's behavior. It will encourage them to produce great output and improve organizational goodwill. Abouraia and Othman [5] say that a transformational leader is a leader who tends to perform the individual success, have high expectations, and give recognition, Sharanya and Himabindu [6] state that transformational leadership style focuses on the team, including the development of the team, the motivation of the team and the collaboration of the employees within the team. Collaboration with employees happens at the various organizational level for a better chance.

According to Sun and Wang [7], if the transformational leadership is implemented properly, it will mostly affect the employees not to quit from the company. Besides that, Arthi and Sumathi [8] mention that transformational leadership gives a great influence on employee's turnover intention. Another thing that is also able to give a significant influence on reducing turnover intention is the individualized consideration dimension. According to Manoppo [9], transformational leadership strongly influences turnover intention. In line with Manoppo's statement, Ariyabuddhiphongs and Kahn [10] state that turnover intention is stricken by transformational leadership. Shah, et al. [11] state that the role of transformational leadership is very important to reduce turnover intention, even with transformational leadership can increase employee involvement in their work and the company. Jauhar, et al. [12] state that the biggest influence on the company is transformational leadership. It will assist the company in employee effectiveness, satisfaction, organizational commitment, and trust. It will also help the company to increase its overall employee performance and leadership. And most importantly, it helps the company to lower turnover intentions. Pravichai and Ariyabuddhiphongs [13], Promchart and Potipiroon [14], and [15] found that transformational leadership significantly affects turnover intention.

\section{Perceived Organizational Support}

According to Robbins and Judge [16], perceived organizational support is the level at which workers trust that the organizations will help their financial problem and appreciate their contribution. Meanwhile, according to Eisenberger and Stinglhamber [17], perceived organizational support (POS) is the 
same as it is explained by Robbin and Judge. Perceived Organizational Support is the perceptions of the employees who trust that the organizations will help their financial problem and appreciate their contribution, which is proven by giving significant benefits to the employees. Perceived Organizational Support gives a big impact on employees' work performances. The employees will work harder when they feel that the organization supports them. This will increase the employees' work performance. Wang and Wang [18] state that if the employees do not feel supported by the organization, their work performance will get worse. They will have a passive attitude toward their work and it might reduce efficiency. According to Liu, et al. [19], the lower the organizational support for employees, the worse the employees' work performance will be. The employees will be lack encouragement and more likely to get difficulties which might encourage them to resign from the company.

Previous research conducted by Choi and Chiu [20], Haar [21], and Nadeem [22], show that the turnover intention is strongly stricken the perceived organizational support. Adan Gok [23] states that employee turnover intensity can be reduced by perceived organizational support. The employees whose organization values and appreciate their efforts tend to stay and minimize their turnover intention. The same statement is stated by Akgunduz and Sanli [24]. They mention that strong organizational support may reduce the employees' turnover intention. Engelbrecht and Samuel [25] and Azis [26] state that perceived organizational support have a strong relationship with the employees' intention to quit. Meanwhile, AlHashmi, et al. [27] found that there is no direct impact of the perceived organizational support on turnover intention. Also, a study conducted by Wong and Wong [28] showed that there is no significant effect of the perceived organizational support on turnover intention.

\section{Workload}

Tarwaka [29] states that workload is the result of the demand for tasks. It is also the result of the work environment including employee skills and behavior, the workplace, and the workers' perceptions. According to Munandar [30] workload is a work condition with job descriptions that have to be finished in a short time. Meanwhile, the Minister of Home Affairs Regulation No. 12 of 2008 stated that workload is the total of job that has to be carried by an organizational unit and a position. Besides that, the workload is not only the product of time norm but also work volume.
Meanwhile, Susiarty, et al. [31] states that a workload that is too high allows employees to consume excessive energy and overstress could happen or vice versa, if the workload is not too high it allows employees to feel the burden and boredom.

Previous research conducted by Rizka, et al. [32] and Suarthana and Riana [33] find that workload has a significant influence on turnover intention. Tulangow [34] also find that there is a big effect of the workload on turnover intention. It is because everyone can think that they can find another job that suits their abilities if the office they are working in now gives them too much work. According to Erat, et al. [35] a high workload will increase the potential for employees to have a desire to leave the company (turnover intention). The results of the study of Suputra [36] and Askiyanto [37] also show that there is a significant effect of workload on turnover intention. Meanwhile, a study conducted by Altahtooh [38] and Pradita and Satrya [39] find that workload gives only a small effect on the employee turnover intention.

\section{Turnover Intention}

According to Mobley [40], the turnover intention is the intention of an employee or a tendency of an employee to quit the job or move to another workplace to another according to their own will. Robbins and Judge [1] describe turnover intention as a degree of employee possibility to quit the company due to the low interest in the current job or the availability of another job alternative. Meanwhile, according to Dharma [41], the turnover intention is the tendency of the employee to find another new job or to quit the company in a short or long period. According to Asriani and Riyanto [42], the high turnover intention will cause losses in various aspects, especially in terms of time, finance, and effectiveness also the efficiency of company management because turnover intention will also have an impact on employees' performance decline. Maska and Riyanto [43] also argued that turnover intention is the desire of employees to deliberately choose to quit the company shortly. If employees cannot accept and like their work, then the desire to do turnover will be major. Several factors affect turnover intention. The factor is the external factor. The external factors include the institutional factors and labor markets such as workspace conditions and supervision. It also includes the employee's characteristics, such as attitude, intelligence, empowerment, gender, age, stress, and length of work, workload, and individual reactions to work [44]. 


\section{CONCEPTUAL FRAMEWORK}

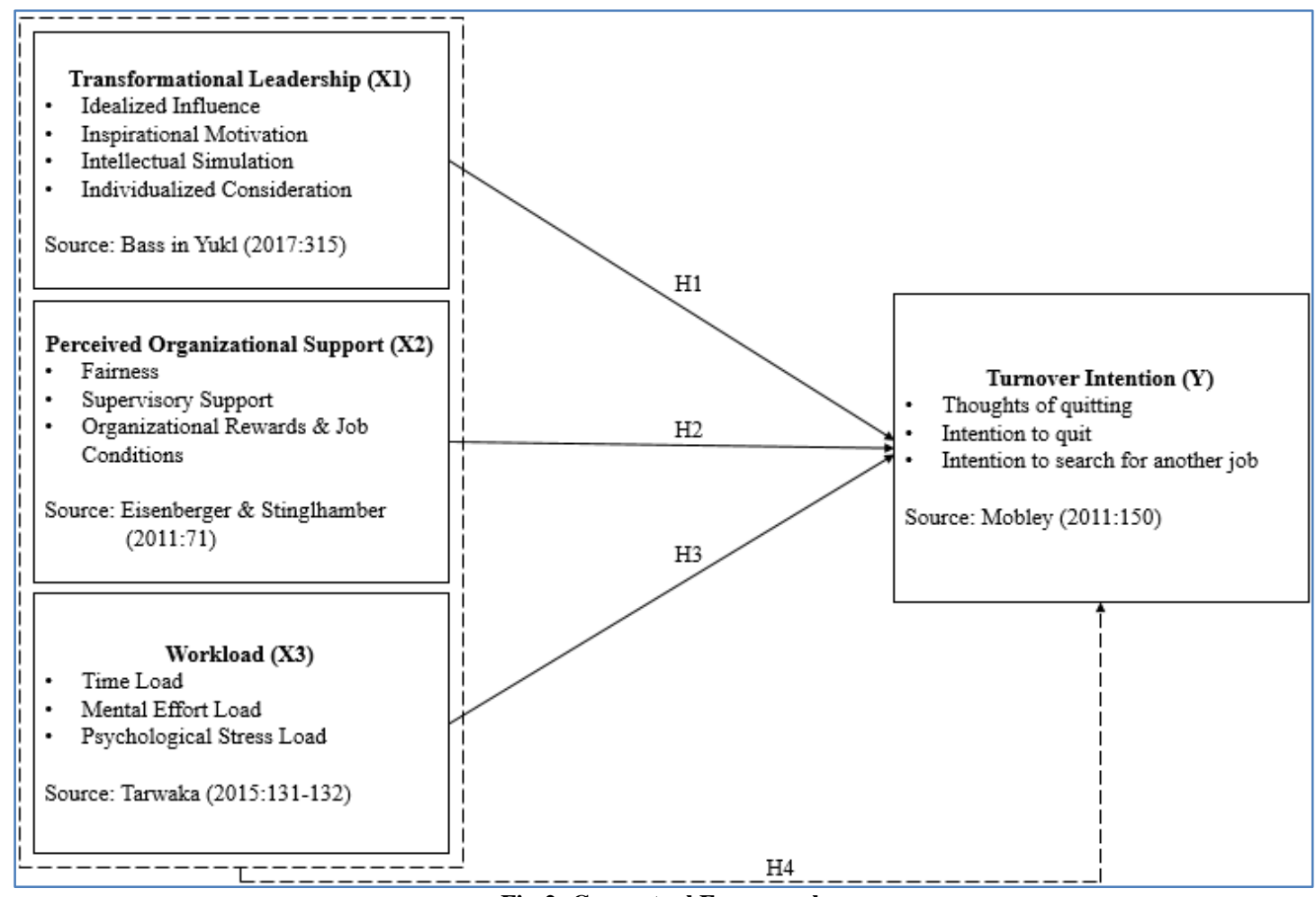

Fig-2: Conceptual Framework

\section{HYPOTHESIS}

H1: Transformational leadership affects turnover intention.

H2: Perceived organizational support (POS) affects turnover intention.

H3: Workload affects turnover intention.

H4: Transformational leadership, perceived organizational support, and workload simultaneously affect turnover intention.

\section{METHODOLOGY}

\section{Population and Sample}

The populations in this study were 134 employees who worked in one of sharia banking in Jakarta. This study used a nonprobability sampling method as well as a purposive sampling method. The determination of the sample uses the Slovin formula to obtain 101 samples.

\section{Data Collection Method}

Data collection method used in this study is a survey method, which is the technique of collecting and analyzing data in the form of opinions from the subjects studied through a questionnaire using a Likert scale of 1-5. According to Sekaran and Bougie [45], the Likert scale of 1-5 is used to measure the person's or group's opinions perceptions, attitudes about social phenomena. The Likert scale uses five degrees of an answer, they are 1 (Strongly disagree), 2 (Disagree), 3 (Slightly Disagree/Neutral), 4 (Agree), and 5 (Strongly agree).

\section{Data Analysis Method}

This research uses quantitative research to measure behavior, knowledge, opinions, and attitudes [46]. The data obtained in this study were analyzed by using the data quality test such as validity test and reliability test. Besides that, the data were also analyzed by using a classic assumption test, hypothesis test, multiple linear regression analysis, and interdimensional correlation matrix tests processed using SPSS (Statistical Product and Service Solutions) version 23.

\section{RESULTS AND DISCUSSION Validity Test Results}

The test was done by comparing the $r$ table value with the calculated r-value. If calculated r-value> $r$ table value then the statement or indicator is interpreted as valid, whereas if calculated $r$-value $<r$ table value then the statement or indicator is interpreted as invalid [47]. The $r$ table value is obtained from degree of freedom $(\mathrm{df})=\mathrm{n}-2,101-2=99$. Then the $\mathrm{r}$ table value obtained is 0,1956 . All validity test results of transformational leadership perceived organizational support, workload, and turnover intention variables are shown as valid, where the calculated r-value is bigger than $r$ table value.

\section{Reliability Test Results}

The test was done by looking at the Cronbach Alpha $(\alpha)$ value. A constructor variable is reliable if it gives Cronbach Alpha value> 0.60 [47]. The reliability 
test results using SPSS 23 program showed that all variables were declared reliable where transformational leadership had Cronbach alpha value of 0,857 , perceived organizational support of 0,901 , the workload of 0,746 , and turnover intention of 0,933 .

\section{Classical Assumption Test Results}

The test includes a multicollinearity test, a normality test, and heteroscedasticity test. The normality test was distributed by viewing KolmogorovSmirnov value. If Asymp. Sig (2-tailed)> 0.05, then the data is normally distributed [47]. The results of this study found that Asymp Sig (two-tailed) value was 0,195 , greater than 0,05 so all data in this study meet the assumptions of normally distributed data.

The aim of the multicollinearity test is to find out whether the regression model correlates with the independent variables. A regression model is considered good if the multicollinearity does not occur. The cut-off values commonly used to indicate multicollinearity are
Tolerance value $<0.10$ and VIF value $>10$ [37]. The results of the study showed that the transformational leadership variable obtained a tolerance value of 0,623 and a VIF value of 1,606. The perceived organizational support variable got a tolerance value of 0,748 and a VIF value of 1,338. Meanwhile, the workload variable got a tolerance value of 0,784 and a VIF value of 1,275. So, in short, it can be stated that the three independent variables did not occur multicollinearity due to the tolerance value $>0.10$ and VIF value $<10$.

To find out whether the regression model has variance inequality from one residual observation to another, researchers performed a heteroscedasticity test. A regression model is considered as a good model if the heteroscedasticity does not occur. The examination of heteroscedasticity indication is to look at the radiant diagram pattern. The characteristics that indicate the absence of heteroscedasticity are if the transmission diagram does not form a pattern and the dots spread below and above the number 0 on $\mathrm{Y}$-axis [37].

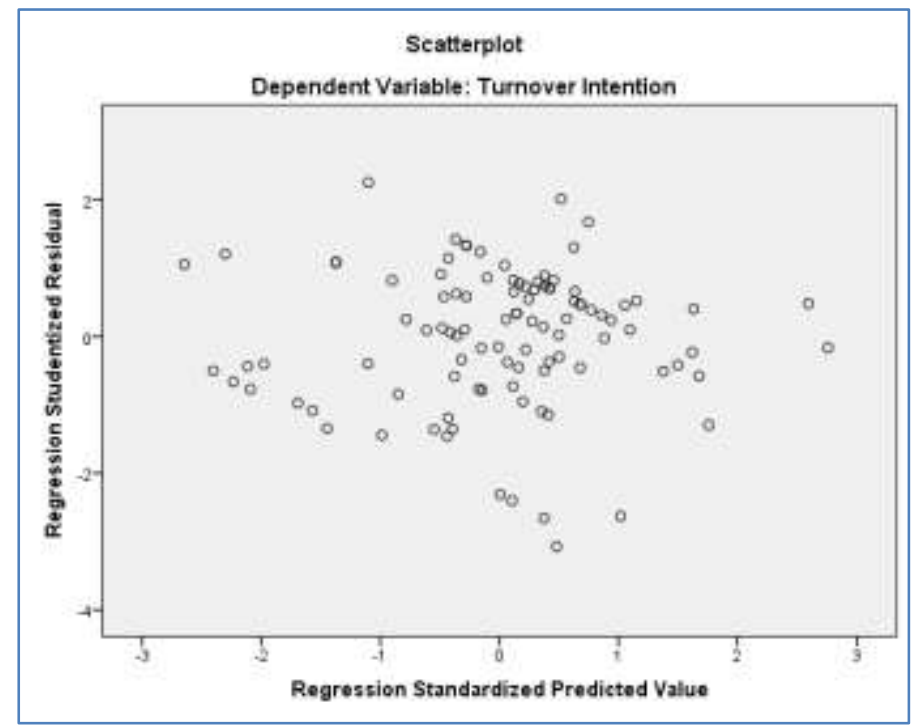

Fig-3: Heteroscedasticity Test Results

Source: The data results were processed with SPSS 23

\section{Multiple Linear Regression Analysis Test Results}

Table-1: Multiple Linear Regression Analysis Test Results Coefficients ${ }^{a}$

\begin{tabular}{|c|c|c|c|c|c|}
\hline \multirow[b]{2}{*}{ Model } & \multicolumn{2}{|c|}{$\begin{array}{l}\text { Unstandardized } \\
\text { Coefficient }\end{array}$} & \multirow{2}{*}{$\begin{array}{c}\begin{array}{c}\text { Standardized } \\
\text { Coefficient }\end{array} \\
\text { Beta } \\
\end{array}$} & \multirow[b]{2}{*}{$\mathbf{t}$} & \multirow[b]{2}{*}{ Sig } \\
\hline & B & Std. Error & & & \\
\hline (Constant) & $-2,474$ & ,666 & & $-3,713$ &, 000 \\
\hline Transformational & & & & & \\
\hline Leadership &, 345 &, 159 & ,207 & 2,167 & ,033 \\
\hline $\begin{array}{r}\text { Perceived } \\
\text { Oroanizational Sunnort }\end{array}$ & 515 & 143 & 314 & 3609 & 000 \\
\hline Workload & & & & & \\
\hline & ,688 & 167 & 350 & 4,114 & ,000 \\
\hline
\end{tabular}

$$
Y=-2,474+0,345 X 1+0,515 X 2+0,688 X 3+e
$$


A value (constant) is $-2,474$, which means that if transformational leadership, perceived organizational support, and workload variables are not carried out properly and accordingly, the employee's desire to leave their jobs is quite major. The minus sign 2,474 in the constant indicates the intensity level of employees wanting to leave the company is currently high. This means that when other companies offer jobs that are more interesting to the employees, the employees will move. The way to fix high turnover intention is to make positive activities or influential independent factors.

Transformational leadership shows a positive regression coefficient of 0,345 . The movement of a positive regression coefficient of 0,345 will make the negative constant value closer to positive so the turnover intention became low. So if the regression coefficient for the other independent variables is constant (unchanged), then the addition of the transformational leadership variable will lower the turnover intention. In short, if the leader implemented the transformational leadership variable properly, the employees' intention and desire to leave the job becomes low. They most likely choose to stay and continue to work in their current company.

Perceived Organizational Support shows a positive regression coefficient of 0,515 . The movement of a positive regression coefficient of 0,515 will make the negative constant value closer to positive so the turnover intention became low. So if the regression coefficient for other independent variables is constant (unchanged), then the addition of perceived organizational support variable will lower the turnover intention rate. It means if perceived organizational support variable in employees is good, this will make the employee's desire to quit becomes low or they will remain loyal to the company and their job.

The workload shows a positive regression coefficient of 0,688 . The movement of a positive regression coefficient of 0,688 will make the negative constant value closer to positive so the turnover intention became low. So if the regression coefficient for other independent variables is constant (unchanged), then the addition of workload variable (the more it fits the employee's ability) will lower the turnover intention rate. It means if the workload variable given to employees is appropriate and not excessive, this will make employees' desire to quit becomes low or they will remain loyal to the company and their job.

\section{Hypothesis Test Results}

The hypothesis test consists of three tests. They are a simultaneous significance test ( $F$ statistical test), an individual parameter significance test (t-test), and a determination coefficient test $\left(\mathrm{R}^{2}\right)$. The simultaneous significance test ( $F$ statistical test) is used to show whether all independent variables included in the model have a simultaneous effect on the dependent variable. If the probability or Sig value $<0.05$ then the model is accepted and has a simultaneous effect on the dependent variable [47]. The results of this study found that the Sig value of 0,000 is less than 0,05 and the calculated $\mathrm{F}$ value of 26,422 is greater than $\mathrm{F}$ table value $(2,698)$. So it can be concluded that transformational leadership, perceived organizational support and workload have a simultaneous effect on turnover intention.

The individual parameter significance test $(t-$ test) shows to which extent the effect of explanatory or independent variables individually in explaining the dependent variable variation [47]. The t table value is obtained from degree of freedom $(\mathrm{df})=\mathrm{n}-2,101-2=$ 99. So the t table value obtained is 1,984 .

1. Transformational leadership partially has a significant effect on turnover intention. This can be seen from calculated $t$ value of 2,167 (greater than $\mathrm{t}$ table $=1,984$ ) and sig value of 0,033 (less than 0,05 ).

2. Perceived organizational support partially has a significant effect on turnover intention. This can be seen from calculated $t$ value of 3,609 (greater than $\mathrm{t}$ table $=1,984$ ) and sig value of 0,000 (less than 0,05$)$

3. Workload partially has a significant effect on turnover intention. This can be seen from calculated $\mathrm{t}$ value of 4,114 (greater than t table $=1,984)$ and sig value of 0,000 (less than 0,05$)$.

The determination coefficient test $\left(\mathrm{R}^{2}\right)$ is used to measure to which extent the model's ability to explain the dependent variable variation [47]. The results of this study indicate the value of Adjusted R Square is 0.433 or $43.3 \%$, which means that the contribution of turnover intention can be explained by transformational leadership, perceived organizational support, and workload variables. And the remaining 56, $7 \%$ is described by other variables which were not examined in this study. They are compensation, career development, job satisfaction, and work environment.

\section{Inter-Dimensional Correlation Matrix Test Results}

Based on correlation results between the dimensions of transformational leadership and turnover intention variables, it is found that the greatest correlation value between the idealized influence dimension and thoughts of quitting dimension at 0,478 . According to Siregar [48], the value of 0,478 is within a fairly strong relationship level category. While the value of the smallest correlation between the inspirational motivation dimension and the intention to quit dimension is 0,295 and is within a weak relationship level category.

Based on correlation results between the dimensions of perceived organizational support and turnover intention variables, it is found that the greatest 
correlation value between organizational rewards and job conditions dimension with the desire to find another job dimension of 0,509. According to Siregar [48], the value of 0,509 falls into a fairly strong relationship category. Meanwhile, the smallest correlation value between the fairness dimension and the desire to find another job dimension of 0,223 and is within the weak relationship category.

Based on the correlation results between the dimensions of workload and turnover intention variables, it is found that the greatest correlation value between the mental workload dimension and wanting to leave dimension of 0,603 . According to Siregar [48], the value of 0,603 falls into a strong category. Meanwhile, the smallest correlation value between the time load dimension and the desire to find another job dimension of 0,125 and is within the very weak relationship category.

\section{CONCLUSIONS AND SUGGESTIONS Conclusions}

According to the hypothesis and analysis test results which have been explained, the conclusions are as follows:

1. According to the result of the correlation matrix test between the dimensions of transformational leadership and turnover intention variables, there has been a high correlation between the idealized influence dimension and the thoughts of quitting dimension. A low correlation was also found between inspirational motivation and the desire to leave dimensions. So, in short, there has been a significant effect of transformational leadership on turnover intention in one of sharia banking in Jakarta.

2. According to the result of the correlation matrix test between the dimensions of perceived organizational support and turnover intention variables, there has been a high correlation between organizational rewards and job conditions dimension with the desire to find another job dimension. A low correlation was also found between fairness and wanting to find another job dimensions. So, in short, there has been a significant effect of the perceived organizational support on turnover intention in one of sharia banking in Jakarta.

3. According to the result of the correlation matrix test between the dimensions of workload and turnover intention variables, there is a high correlation between mental workload and wanting to leave dimensions. A low correlation was also found between time load and wanting to find another job dimensions. So, in short, there has been a significant effect of workload on turnover intention in one of sharia banking in Jakarta.

4. There has been a significant effect of transformational leadership, perceived organizational support, and workload simultaneously or together on turnover intention in one of sharia banking in Jakarta.

\section{Suggestions}

According to the result of this study and the conclusions that have been described, the author proposes several suggestions that can be taken into consideration in lowering turnover intention:

1. Suggestions for transformational leadership affecting turnover intention

a. The leaders can conduct small discussions or briefings that are administrated on a daily basis by providing directions and explanations of the work that employees must do and targets to be achieved.

b. The leaders must always monitor and supervise employee's work progress and provide advice and evaluation of employee work.

c. The company provides training programs such as the Leadership Development Program for the leaders on how to be good role models and have a positive impact on their employees.

2. Suggestions for perceived organizational support affecting turnover intention

a. The company needs to make improvements by always providing regular training according to the employee's needs and the company opens promotion opportunities for all employees.

b. Companies need to improve the safety of employees at work (such as tightening the security system by imposing insurance for all employees) and hold gatherings or outings with employees to reduce employee stress at work.

3. Suggestions for workload affecting turnover intention

a. Companies need to make improvements to the existing work environment so it becomes more comfortable so employees can concentrate and enjoy their work properly without feeling the excessive burden.

b. Companies can increase employees' competence by improving and developing a training system so that employees are ready to face workload challenges.

4. Suggestions for the next researchers

It is recommended for future researchers who want to examine regarding the variables used in this study, which are Transformational Leadership, Perceived Organizational Support, Workload, and Turnover Intention so that further research can develop other variables including compensation variables, work environment, career development, job satisfaction, and so on. Further researchers can also research different objects such as in manufacturing companies with more respondents in different research objects. 


\section{REFERENCES}

1. Robbins, S. P., \& Judge, T. A. (2015). Organizational Behavior (Global Edition). Pearson Education Limited. United States of America.

2. Yukl, G. (2017). Kepemimpinan Dalam Organisasi (Edisi Ketujuh). Indeks. Jakarta.

3. Mickahail, B. K., \& Aquino, C. T. E. de. (2019). Effective and Creative Leadership in Diverse Workforces: Improving Organizational Performance and Culture in the Workplace. Palgrave Macmillan. Switzerland.

4. Sultana, S., \& Jabeen, S. (2018). Bridging the relationship of Transformational Leadership and Turnover intentions with mediating effect of employee engagement. InTraders International Trade Academic Journal, 1(1), 2660-4408.

5. Abouraia, M. K., \& Othman, S. M. (2017). Transformational Leadership, Job Satisfaction, Organizational Commitment, and Turnover Intentions: The Direct Effects among Bank Representatives. American Journal of Industrial and Business Management, 07(04), 404-423.

6. Sharanya, T., \& Himabindu, P. (2017). Impact of Transactional and Transformational Leadership : a Study on Employees Perception Towards Employee Retention in It Sector. International Journal of Current Engineering And Scientific Research (IJCESR), 4(9), 64-69.

7. Sun, R., \& Wang, W. (2016). Transformational leadership, employee turnover intention, and actual voluntary turnover in public organizations. Public Management Review, 19(8), 1124-1141.

8. Arthi, R., \& Sumathi, G. (2018). Transformational leaders and turnover intention: Moderating role of followers' emotional intelligence. International Journal of Mechanical Engineering and Technology, 9(11), 2232-2244.

9. Manoppo, V. P. (2020). Transformational leadership as a factor that decreases turnover intention: a mediation of work stress and organizational citizenship behavior. TQM Journal.

10. Ariyabuddhiphongs, V., \& Kahn, S. I. (2017). Transformational leadership and turnover intention: The mediating effects of trust and job performance on café employees in Thailand. Journal of Human Resources in Hospitality and Tourism, 16(2), 215233.

11. Shah, S. H. A., Saeed, M. A., Yasir, M., Siddique, M., \& Umar, A. (2018). The Impact of Transformational Leadership on Turnover Intentions Directly and Through Talent Engagement in the Banking Sector of Twin Cities of Pakistan.

12. Jauhar, J., Ting, C. S., Rahim, N. F. A., \& Fareen, N. (2017). The impact of reward and transformational leadership on the intention to quit of Generation Y employees in oil and gas industry: Moderating role of job satisfaction. Global Business and Management Research: An International Journal, 9(4), 426-442.
13. Pravichai, S., \& Ariyabuddhiphongs, V. (2018). Transformational leadership and turnover intention: the mediating effects of right speech (Samma Vaca) and trust in the leader. Journal of Management, Spirituality, and Religion, 15(3), 253-272.

14. Promchart, K., \& Potipiroon, W. (2020). Transformational leadership and turnover intentions among school teachers in the deep south of Thailand. Journal of Behavioral Science, 15(2), 16-37.

15. Maaitah, A. M. (2018). International Review of Management and Marketing The Role of Leadership Style on Turnover Intention. International Review of Management and Marketing, 8(5), 24-29.

16. Robbins, S. P., \& Judge, T. A. (2017). Perilaku Organisasi (Cetakan Kelima). Salemba Empat. Jakarta.

17. Eisenberger, R., \& Stinglhamber, F. (2011). Perceived Organizational Support: Fostering Enthusiastic and Productive Employees. American Psychological Association. Washington D.C.

18. Wang, Q., \& Wang, C. (2020). Reducing turnover intention: perceived organizational support for frontline employees. Frontiers of Business Research in China, 14(1).

19. LIU, H., HUANG, Y., \& JIANG, S. (2016). The Impact of Optimism on Turnover Intention for Low-Wage White-collars: The Moderating Effect of Perceived Organizational Support. DEStech Transactions on Computer Science and Engineering, mcsse, 483-488.

20. Choi, H., \& Chiu, W. (2017). Influence of the perceived organizational support, job satisfaction, and career commitment on football referees' turnover intention. Journal of Physical Education and Sport, 17(3), 955-959.

21. Haar, J. M., De Fluiter, A., \& Brougham, D. (2016). Abusive supervision and turnover intentions: The mediating role of perceived organizational support. Journal of Management and Organization, 22(2), 139-153.

22. Nadeem, K., Khan, M. A., Imtiaz, N., \& Iftikhar, Y. (2019). Turnover Intention and Perceived Organizational Support; Mediating Role of Work Engagement and Organizational Commitment European Scientific Journal ESJ, 15(10), 222-236.

23. Adan Gok, O., Akgunduz, Y., \& Alkan, C. (2017). The Effects of Job Stress and Perceived Organizational Support on Turnover Intentions of Hotel Employees. Journal of Tourismology, 3(2), 23-32.

24. Akgunduz, Y., \& Sanli, S. C. (2017). The effect of employee advocacy and perceived organizational support on job embeddedness and turnover intention in hotels. Journal of Hospitality and Tourism Management, 31, 118-125.

25. Engelbrecht, A., \& Samuel, O. M. (2019). The effect of transformational leadership on intention to 
quit through perceived organizational support, organizational justice, and trust. South African Journal of Economic and Management Sciences, 22(1).

26. Azis, E., Prasetio, A. P., \& Utomo, K. H. (2019). Overcoming Turnover Intention Problems: DirectIndirect Model To Identify the Effect of Perceived Organizational Support and Job Satisfaction in Service-Based Organizations. Jurnal Aplikasi Manajemen, 17(3), 555-566.

27. AlHashmi, M., Jabeen, F., \& Papastathopoulos, A. (2019). Impact of leader-member exchange and perceived organizational support on turnover intention: The mediating effects of psychological stress. Policing, 42(4), 520-536.

28. Wong, Y.-W., \& Wong, Y. (2017). The Effects Of Perceived Organizational Support and Affective Commitment on Turnover Intention. Journal of Chinese Human Resource Management, 8(1), 2-21.

29. Tarwaka. (2015). Ergonomi Industri: Dasar-dasar Pengetahuan Ergonomi dan Aplikasi di Tempat Kerja (Revisi Edisi II). Harapan Press Solo. Surakarta.

30. Munandar, A. S. (2014). Psikologi Industri dan Organisasi. Universitas Indonesia Press. Jakarta.

31. Susiarty, A., Suparman, L., \& Suryatni, M. (2019). the Effect of Workload and Work Environment on Job Stress and Its Impact on the Performance of Nurse Inpatient Rooms At Mataram City General Hospital. Scientific Research Journal, VII(VI).

32. Rizka, F. M., Ardiana, I. D. K. R., \& Andjarwati, T. (2020). The Effect of Workload, Pay Satisfaction, Work Satisfaction on Turnover Intention, and Performance of Employees of Angkasa Pura Logistic Indonesia. International Journal of Social Science and Economics Invention, 06(02), 234-241.

33. Suarthana, J. H. P., \& Riana, I. G. (2016). The Effect of Psychological Contract Breach and Workload on Intention to Leave: Mediating Role of Job Stress. Procedia - Social and Behavioral Sciences, 219, 717-723.

34. Tulangow, M. J., Saerang, D. P. E., \& Rumokoy, F. S. (2018). The Effect Of Job Stress, Work Environment, and Workload on Employee Turnover Intention (Case Study at PT. Wika Reality Manado). Journal EMBA, 6(2), 474-482.

35. Erat, S., Kitapçi, H., \& Çömez, P. (2017). The effect of organizational loads on work stress, emotional commitment, and turnover intention. International Journal of Organizational Leadership, 6(2), 221-231.

36. Suputra, P. M. A., Yuesti, A., \& Sudja, I. N. (2018). the Effect of Work Satisfaction, Organizational Commitment, and Workload on Turn Over Intention on Pt. Bank Rakyat Indonesia (Persero) Tbk Unit Sekanca Denpasar Gajah Mada. RA Journal Of Applied Research, 4(8), 1939-1945.

37. Askiyanto, M., Soetjipto, B. E., \& Suharto. (2018).
The Effect of Workload, Work Stress, and Organizational Climate on Turnover Intention with Work Satisfaction as an Intervening Variable (Study at PT BRI Life and Health Insurance of Malang). European Journal of Business and Management, 10(12), 61-70-70.

38. Altahtooh, U. A. (2018). The Effect of Job Satisfaction and Workload on IT Project Employee Turnover Intention in the Madinah Government of Saudi Arabia. International Journal of Business and Social Science, 9(8), 107-115.

39. Pradita, N. N., \& Satrya, A. (2019). The Influence of Empowerment and Workload on Turnover Intention through the Mediation of Emotional Exhaustion on Indonesian Garment Workers. International Journal of Scientific \& Engineering Research, 10(1), 82-87.

40. Mobley, W. H. (2011). Pergantian Karyawan: Sebab, Akibat dan Pengendaliannya. PT Pustaka Binaman Pressindo. Jakarta.

41. Dharma, S. (2013). Manajemen Kinerja: Falsafah, Teori dan Penerapannya. Pustaka Pelajar. Yogyakarta.

42. Asriani, I., \& Riyanto, S. (2020). The Impact of Working Environment, Compensation, and Job Satisfaction on Turnover Intention in Public Service Agency. IOSR Journal of Business and Management, 22(5), 13-19.

43. Maska, H., \& Riyanto, S. (2020). The Influence of Job Embeddedness, Salary, and Organizational Commitment against the Turnover Intention of the Employees in the Marketing Division at Pharmaceutical Laboratories Industry in Jabodetabek. IOSR Journal of Business and Managemen, 22(2), 29-35.

44. Syamsurizal, \& Permana, E. (2019). Employees ' Turnover Intention Of Mice Industry In Jakarta Indonesia. IOSR Journal of Business and Management, 21(7), 56-64.

45. Sekaran, U., \& Bougie, R. (2017). Metode Penelitian Untuk Bisnis Pendekatan Pengembangan-Keahlian. Salemba Empat. Jakarta.

46. Cooper, D. R., \& Schindler, P. S. (2017). Metode Penelitian Bisnis. Salemba Empat. Jakarta.

47. Ghozali, I. (2013). Aplikasi Analisis Multivariete dengan Program IBM SPSS 23. Badan Penerbit Universitas Diponegoro. Semarang.

48. Siregar, S. (2013). Metode Penelitian Kuantitatif Dilengkapi dengan Perbandingan Perhitungan Manual dan SPSS. Kencana Prenada Media Group. Jakarta.

49. Otoritas Jasa Keuangan (OJK). (2019). Snapshot Perbankan Syariah Indonesia Juni 2019. 20 September 2019.

50. Peraturan Menteri Dalam Negeri No. 12 Tahun 2008 Pedoman Analisis Beban Kerja di Lingkungan Departemen Dalam Negeri dan Pemerintah Daerah. 20 Februari 2008. Lembaran Negara Republik Indonesia Tahun 2008. Jakarta. 